\title{
Immigration Control as Self-Defense
}

\author{
Mollie Gerver
}

\section{M.Gerver@essex.ac.uk}

\section{American Political Science Association, September 2020}

\begin{abstract}
This article defends the claim that citizens are justified in supporting immigration restrictions which are necessary to protect access to resources which (a) they have a claim right to and which (b) they and not migrants require to sustain their lives. Moreover, citizens are justified in supporting such restrictions even when it means blocking migrants' access to lifesustaining resources so long as (a) migrants lack a claim right to these resources and (b) the number of migrants seeking entrance is below a given threshold. Though citizens act permissibly in supporting restrictions in such cases, and act permissibly in voting for policymakers supporting such restrictions, the policymakers themselves often act impermissibly in implementing such restrictions. This is because the actions which citizens are justified in pursuing to defend their own lives are distinct from the actions which policymakers are justified in pursuing to defend the lives of citizens.
\end{abstract}


Immigrants generally increase the medium wage of native workers, pay more in taxes than they use in resources, and contribute in countless non-monetary ways to the culture and intellectual life of their adopted countries. They also dramatically increase their own resources and liberties when given the option to migrate, creating a strong prima facie case for open borders. $^{1}$

Despite the prima facie case for open borders, the short-term impacts of immigrants can be lethal for some.

Consider the case of Siama. On a rainy morning in March 2012, she was sitting on a sofa in her Juba home, comprised of a dirt floor, a couch, and straw walls. The only visible food was a sack of rice leaning against her west-facing fence, and she was unemployed, lacking nutrients necessary for survival. She decided that the government should limit the number of migrants entering and working in South Sudan. "Most jobs are in hotels, and most of the hotels are owned by Somalis, Eritreans and Ethiopians," she explained. "South Sudanese cannot get jobs." ${ }^{2}$

Siama acknowledged that migrants might help the South Sudanese economy eventually, creating more jobs than they take. But this would take time, and Siama lacked time. To survive she needed a job as soon as possible, and so felt justified in limiting inward migration.

This article considers whether and when citizens like Siama are permitted to support immigration control to defend their survival, and whether policymakers act permissibly in acting on behalf. More specifically, it considers whether citizens and policymakers act permissibly in restricting immigration to protect citizens' access to "adequate food, water, clean air, shelter, health, and a livable environment."3

\footnotetext{
${ }^{1}$ Arash Abizadeh, "The Special-obligations Challenge to More Open Borders," in (eds.) Sarah Fine and Lea Ypi, Migration in Political Theory, Oxford: Oxford University Press 2016; Joseph Carens, "Aliens and Citizens: The case for open borders," Review of Politics 49(2)(1987): 251-273 at 259; Javier S. Hidalgo, Unjust Borders: Individuals and the ethics of immigration, Routledge 2019 at 37-41; Kieran Oberman, "Immigration Control as a Human Right," in (eds.) Sarah Fine and Lea Ypi, Migration in Political Theory, Oxford: Oxford University Press 2016.

2 Personal interview with Siama, Juba, 16 March 2012

${ }^{3}$ Anna Stilz, Territorial Sovereignty, Oxford: Oxford University Press 2019 at 132.
} 
Of course, there are other reasons citizens might be permitted to support immigration control, and other reasons policymakers may be permitted to support controls on their behalf. Perhaps citizens are part of a collective association, and associations are permitted to decide who is a member and who is not. ${ }^{4}$ Like a tennis club deciding who can join, a state's citizens and their representatives can decide who to admit and who to exclude. Alternatively, perhaps citizens and their representatives are permitted to control immigration because an increase in migrants can undermine the trust that exists between citizens and their institutions, essential for democratic functioning. ${ }^{5}$ Some claim citizens have a right to shape the culture of their society, and immigrants can dramatically change this culture. ${ }^{6}$ Still others claim states in general are permitted to control immigration to support the poorest living within each state, who may suffer from a major increase in migration. ${ }^{7}$ Less controversially, states are likely permitted to limit migration that has such a detrimental effect on the economy that the harms for nearly all would outweigh the benefits for some. ${ }^{8}$ There are other justifications for immigration control, but this article focuses one more personal: that of personal self-defense.

Personal self-defense is not about harms and benefits in general, or the institutions of society and the association that exists between citizens. It is not about whether all citizens are

\footnotetext{
${ }^{4}$ Christopher Heath Wellman, "Immigration and Freedom of Association," Ethics 119(1)(2008):109-141. For a response, see Sarah Fine, "Freedom of Association is not the Answer," Ethics 120(2)(2010):338-356.

${ }^{5}$ Matthew Gibney, "Liberal Democratic States and Responsibilities to Refugees," The American Political Science Review 93(1999) 169-81 at 174-175.

${ }^{6}$ David Miller, "Immigration: The Case for Limits," in (eds.) A. Cohen and C. Wellman, Contemporary Debates in Applied Ethics, Malden, MA: John Wiley \& Sons 2014 at 363-375; Michael Walzer, Spheres of Justice, Basic Books 1983 at 61. For an opposing view, see Arash Abizadeh, "Does liberal Democracy Presuppose a Cultural Nation? Four arguments," American Political Science Review, 96(2002):495-509; Andrew Mason, Community, Solidarity and Belonging, Cambridge: Cambridge University Press 2000 and Hidalgo 2019 ibid at 47-48. Anna Stilz defends a related and, I think, more nuanced and compelling claim: citizens have certain "practice-based territorial interests" which are second-order interests to access basic interests in a certain way. For example, Bedouins have an interests in accessing food (a basic interest) via nomadic cattle herding (a practice-based interest), and may have a right to prevent outsiders from entering territory necessary for this way of life, assuming such prevention does not harm the practice-based territorial interests or the basic interests of those denied entrance. See Stilz 2019 ibid at 167-175. 7 Steven Macedo, “The Moral Dilemma of U.S. Immigration Policy: Open Borders Versus Social Justice?” in (ed.) C. Swain, Debating Immigration, New York: Cambridge University Press 2007 at 63-81 and Joseph Carens, "Migration and Morality: A liberal egalitarian perspective" in (eds.) Brian Barry and Robert E. Goodin, Free Movement: Ethics issues in the transnational migration of people and money, Pennsylvania State University Press 1992. For opposing views, see Ryan Pevnik, "Social Trust and the Ethics of Immigration Policy," Journal of Political Philosophy 17(2)(2009):146-167 and Hidalgo 2019 ibid at 41-46.

${ }^{8}$ Hidalgo 2019 ibid at 65; Joseph Carens, J. (1987). Aliens and citizens: The case for open borders. The Review of Politics, 49(2)(1987):251-273 at 260; Oberam 2016 ibid at p. 33.
} 
permitted to limit migration to protect the poorest among them, but whether the poor are permitted to protect themselves. It is common for individuals to claim they support immigration controls to protect themselves. ${ }^{9}$ Such claims are widespread in agrarian societies in the Global South where most migration occurs, and where increases in migration can decrease life-sustaining land accessible to local farmers. They are widespread in societies transitioning from periods of war, where employment opportunities are limited, and a major increase in migration means continued unemployment for some. They are widespread in high and middle-income societies without reliable public healthcare, where an increase in inward migration can mean losing one's job, one's health insurance, and so one's life-saving medical treatment. In these and other cases, it is not clear if individual citizens are permitted to support the exclusion of migrants for survival-based goods, given the needs of migrants and the violence required for their exclusion. Nor is it clear when policymakers are permitted to prevent inward migration. If Siama is permitted to vote for policymakers restricting migration, it is not clear if these policymakers are permitted to act on her behalf.

The discussion of what citizens and policymakers are permitted to do when survival is at stake has been largely overlooked in discussions on immigration ethics. It is often claimed, by proponents of both open and closed borders, that states can clearly limit immigration in any given year to protect the survival of citizens, as when states prevent new migrants entering during a pandemic, or prevent new migrants arriving when doing so protects life-sustaining land. ${ }^{10}$ But this claim - that states can limit inward migration to protect citizens' basic needs -

\footnotetext{
${ }_{9}$ Mary Holms and Natha Manning “'Them that Runs the Country Don't Know What They're Doing': Political Dissatisfaction Amongst Members of the Working Class," The Sociological Review 61(2013): 479-498 at 492; Heidi Beirich and Dwayne Woods, "Globalisation, Workers, and the Northern League," Western European Politics 23(1)(2000):130-143; Jozef Merkx, 'Refugee Identities and Relief in an African Borderland: A study of northern Uganda and southern Sudan,' Refugee Survey Quarterly 21(1)(2002):113-146 at 122-124; Urmilla Bob, “LandRelated Conflicts in Sub-Saharan Africa," African Journal on Conflict Resolution 10(2)(2010):49-64 at 53.

${ }^{10}$ For example, Anna Stilz, asks us to imagine two groups, Group A and B, where A can only protect its preferred way of life if denying entrance to group B, but will not lose any basic necessities if admitting group B. Stilz states that, "Group A has a stringent duty to grant territorial occupancy to Group B, at whatever cost to their preferred way of life, up to the point where" it can no longer provide group A with "adequate food, water, clean air, shelter, health, and a livable environment." A has no duty to grant entrance if it lacks these necessities, and she takes as axiomatic. Similarly, Luara Ferrocioloi argues that states should accept "a presumptive right to immigrate on the part of refugees" but also "a right on the part of citizens not to bear unreasonable costs when providing membership" to such refugees, including baring costs that would undermine "general welfare." Assuming general welfare includes the lives of citizens, it seems that states can prevent the entrance of some refugees to protect the lives of citizens. See Anne Stilz 2019 ibid at p. 168 and 175; See, also, Abizadeh 2016 ibid; Carens 1987 ibid at 259; Michael Dummett, On Immigration and Refugees, London and New York: Routledge 2001 at 14 and 50-52; Luara
} 
is far from obvious. Imagine a state prevents millions of migrants fleeing famine from arriving because this will lead to a slight short-term strain on health services, leading to two citizens failing to access life-saving cancer treatment. It seems citizens and policymakers have no right to defend two citizens' lives at the expense of millions of others. The question of when citizens and policymakers act justifiably requires moving beyond the mere empirical question of when lives are at stake; it requires exploring when lives at stake justifies the use of force, and when authorizing others to use such force is justified.

The article first focuses on what citizens are permitted to do for themselves. Section 1 argues that citizens are justified in voting for policymakers supporting immigration restrictions necessary to protect access to resources which (a) these citizens have a claim right to and which (b) they and not migrants require to sustain their lives. Section 2 defends the claim that citizens are justified in voting for policymakers supporting restrictions which protect resources which migrants also require to sustain their lives, so long as (a) migrants lack a claim right to these resources which citizens possess, and (b) the number of migrants seeking entrance is below a given threshold. Section 3 demonstrates that the above reasoning can explain why immigration restrictions during a pandemic are often justified.

Section 4 focuses more closely on the conditions of necessity and proportionality. I clarify that immigration control aimed at defending lives must be necessary for such defense, and this necessity condition is rarely met for policymakers even if met for citizens voting for these policymakers. I further demonstrate that immigration restrictions grounded in self-defense often lack proportionality for policymakers, even if proportional for citizens voting for these policymakers. An implication is that citizens often act permissibly in voting for policymakers supporting immigration controls while the policymakers calling for such controls act impermissibly.

Ferracioli, “The Appeal and Danger of a New Refugee Convention," Social Theory and Practice 40(1)(2014):123144 at 132; 


\section{Claim Rights and Self-Defense}

In this section I defend the claim that citizens are morally permitted to vote for policymakers supporting immigration restrictions necessary to protect access to resources which they have a claim right to, and which they and not migrants require to sustain their lives. I defend this claim with reference to citizens aiming to protect two types of resources: land and jobs.

\subsection{Land}

Sometimes farmers support political parties limiting the entrance of migrants who would otherwise have access to farmers' land. ${ }^{11}$ This support is justified when farmers have an independent claim right to this land, and only they depend on this land for survival.

This claim is defended with the following argument:

1. If $\mathrm{X}$ has a claim right to a resource, and only $\mathrm{X}$ is dependent on this resource to survive, she is permitted to use force against $Y$ to prevent $Y$ from accessing this resource, even if $\mathrm{Y}$ also has a claim right to this resource.

2. Sometimes citizens have a claim right to land and also need this land to survive.

3. These citizens are therefore permitted to use force to prevent others from entering a given piece of land which only they depend on to survive.

4. Many citizens are unable to use such force themselves.

5. When $X$ is permitted to use force against $Y$ to access resources she has a claim right to, and which only she needs to survive, she can permissibly support $\mathrm{Z}$ utilizing such force if she is unable to do so herself.

\footnotetext{
11 Koen Vlassenroot and Chris Huggins, "Migration and Conflict in Eastern D.R. Congo," Eco-Conflicts 3(4)(2004):1-4; James Fearon and David Laitin, World Development 39(2):199-211; Annelies Zoomers, "Globalisation and the Foreignisation of Space: Seven Processes Driving the Current Global Land Grab," The Journal of Peasant Studies 37(2)(2010):429-447; Richard Black and Mohamed Sessay, "Forced Migration, Land-Use Change and Political Economy in the Forest Region of Guinea," African Affairs 96(385)(1997):587-605. Richard E. Bilsborrow and Pamela F. DeLargy, "Land Use, Migration, and Natural Resource Deterioration: The Experience of Guatemala and Sudan," Population and Development Review 16 (1990):125-147. Limited land is also a reason individuals migrate. When they do, they sometimes contribute to increased competition over resources in the states they migrate to. See "Climate Change-Induced Migration and Violent Conflict," Political Geography 26(2007):656673 and Michelle Leighton, "Desertification and Migration," in (eds.) Pierre Marc Johnson, Karel Mayrand and Marc Paquin, Governing Global Desertification, Oxford and New York: Routledge.
} 
6. Therefore, when citizens have a claim right over land which only they depend on for survival, but they are unable to forcibly prevent others from accessing this land, they can permissibly support their government preventing others from accessing this land via immigration control.

The first premise describes three mutually sufficient conditions for an individual to permissibly use necessary force against another:

A. An individual has a claim right to a resource

B. They are dependent on this resource for survival and

C. The other individual is not dependent upon this resource for survival.

Establishing when one has a claim right to a resource would require establishing a broader theory of justice. Perhaps an individual has a claim right to a resource if, under a world of equality of opportunity, ${ }^{12}$ or equality of welfare, or quality of resources, ${ }^{13}$ they would access this resource or a resource of equal value. Some claim an individual has a claim if, in a world where all have enough to live a decent life, or a sufficiently autonomous life, they would access this resource. ${ }^{14}$ I shall not attempt to establish a broader theory of distributive justice, but for ease of discussion, assume this: a person has a claim right to at least utilize a resource if she has been utilizing it her whole life, is dependent on it to plan her life, and has a reasonable expectation that she will be able to continue utilizing this resource. This assumption is accepted by a range of scholars and case law. ${ }^{15}$ Just like an individual takes on squatters' rights after living in a house for long enough, an individual takes on rights to use other resources if they have used them

\footnotetext{
12 Rawls 2001: section 13; Richard Arneson, “Equality and Equality of Opportunity for Welfare," Philosophical Studies 56(1)(1989)77-93 at 85. Alternatively, a person has a claim right to land if this amount of land is necessary for obtaining equality of opportunity. This understanding of equality of opportunity is consistent with those who claim that equality of opportunity has only narrow application. See, for example, Benjamin Sachs, "The Limits of Fair Equality of Opportunity," Philosophical Studies 160(2)(2012):323-343.

${ }^{13}$ A more nuanced principle, consistent with Dworkin, would hold that one has a claim right to a piece of land only if, in a world where nobody was jealous of another's holdings, one would have ownership over this land. See Ronald Dworkin, "What is Equality? Part 2: Equality of Resources," Philosophy and Public Affairs 10(1981): 283-345 at 290.

${ }^{14}$ Liam Shields, Just Enough: Sufficiency as a Demand for Justice, Edinburgh: Edinburgh University Press 2016 at Ch. 4.

${ }^{15}$ Anna Stilz, "Nations, States, and Territory." Ethics 121(3)(2011):572-601 and "Occupancy Rights and the Wrong of Removal." Philosophy and Public Affairs 41(4)(2013):324-356; Jeremy Waldron, "Superseding Historic Injustice." Ethics 103(1)(1992):4-28; Cara Nine, "The Wrong of Displacement: The Home as Extended Mind." The Journal of Political Philosophy 26(2)(2018): 240-257; Robert Goodin, "Compensation and Redistribution," in Nomos XXXIII, ed. John Chapman, New York: NYU Press 1991 at 143-177; Michael Heller and Christophoer Serkin, "Revaluing Restitution: From the Talmud to Postsocialism," Michigan Law Review (97)(6)(1999) 1385-1412.
} 
for long enough. ${ }^{16} \mathrm{I}$ accept this for simplicity; if you reject it, then simply fill in your preferred theory of claim rights.

If individuals have claim rights to certain resources, what ought to be done when two individuals have equal claim rights, but the resource can only be used by one? If one person is dependent on this resource for survival and the other is not, it seems the resource ought to be given to the agent dependent on it for survival. When this agent can only access it by using force against the other agent, it seems she has a liberty right to do so. After all, she has a right to life, this right is undermined by another agent using a resource to which she has a claim, and she can only access this resource by using force against the other agent. ${ }^{17}$ While the other agent also has a claim right to this resource, this other agent can only protect his claim by letting the first agent die. This seems like a cost too high to pay, especially given that the first agent has a claim right as well. If this is a price too high to pay, then he lacks a liberty right to access this resource, and acts wrongly in attempting to access this resource. He is therefore liable to defensive harm if this is necessary to prevent him from accessing this resource.

Note what I am not claiming. I am not claiming that we can always use force against others accessing resources which we have claim rights over and others do not. If $\mathrm{X}$ has a ventilator which is not necessary for her survival, she might not be permitted to use physical force against others who require her ventilator to survive. Nor am I claiming a person has a right to a resource solely because they are dependent on it for survival. Perhaps $\mathrm{X}$ is not permitted

\footnotetext{
${ }^{16}$ At least, one takes on such rights if the resource is less than a given value; a millionaire might not have a right to continue using a Ferrari, but someone with a laptop might have a right to continue using the laptop. In other words, the right to access resources which one has grown dependent upon to fulfil one's plans is limited by distributive constraints, such as equality of resources or equality of opportunity. For a defense of this claim, see Heller and Serkin ibid and Catherine Lu, "Delivering the Goods and the Good" in eds.) David Cyzenhaus and Mayo Moran, Calling Power to Account: Law, Reparations, and the Chinese Canadian Head Tax Case, in Toronto: Toronto University Press 2005:147-164 at 155-159; Jon Elster, "On Doing What We Can: An argument against postCommunist restitution and retribution." East European Constitutional Review 1(2)(1992):15; Pablo Kalmanovitz, "Corrective Justice vs. Social Justice in the aftermath of War," in (eds.) Morten Bergsmo, César Rodríguez Garavito, Pablo Kalmanovitz and Maria Paula Saffon, Distributive Justice in Transitions, Oslo: Torkel Opsahl Publisher, International Peace Research Institute 2010; Christopher Kutz, “Justice in Reparations: The Cost of Memory and the Value of Talk," Philosophy and Public Affairs 32(3)(2004):277-312 at 301-302; Stilz 2013 ibid at 353-354; Waldron 1992 ibid at 24-28.

${ }^{17}$ Even those who disagree about when we can use other person's bodies or resources to save our lives agree that we can forcibly access our own resources to save our own life. See Jonathan Quong, "Killing in Self-Defense," Ethics 119(3)(2009):507-537 at 527; Kimberly Ferzan, "Self-Defense, Permissions and the Means Principle: A Reply to Quong," Ohio State Journal of Criminal Law 8(2)(2011):503-513.
} 
to use $Y^{\prime}$ s expensive and rare ventilator merely because $X$ is dependent on it for survival and $\mathrm{Y}$ is not, if $\mathrm{X}$ has no claim right to the ventilator. I take no stance on such cases, and am merely claiming that when $\mathrm{X}$ has a claim right to a resource which she also depends on for survival, she can permissibly use force against others attempting to use this resource who are not dependent on it for survival, including those who might also have a claim right to this resource. If two individuals have a joint claim right to a ventilator that can only be used by one, the one who needs it for survival can use necessary force against the other.

Within agrarian societies, if individuals have lived on their land for long enough, and have planned their lives around this land, they have a claim right to this land. Many are also dependent on this land for survival, as in Ethiopia, Rwanda, and Burundi, where one less square foot of land for the average farmer can mean the difference between nutrients to survive and life-threatening malnutrition. ${ }^{18}$ Individuals relying on such land are permitted to stop others not dependent on this land - including citizens and non-citizens - from accessing this it, assuming this is necessary for survival. They can put up a fence, fire a warning shot against those attempting to use this land, and even directly use force against those attempting to use this land.

In practice, such actions are often ineffective. In Ethiopia individuals are unable to continue accessing life-sustaining land if high-income migrants buy this land from corrupt officials, both occupying and forcing citizens off such land. If these citizens can only avoid this outcome by supporting increased limits on inward migration, then such support would be justified.

It would be justified because of the fifth step in the argument: when $\mathrm{Y}$ is liable to force from $\mathrm{X}$ so that $\mathrm{X}$ can continue accessing resources she has a claim right over, and which only she needs for survival, she can permissibly support $\mathrm{Z}$ utilizing such force instead if she is unable to do so herself. ${ }^{19}$ For example, if $\mathrm{X}$ is dependent on a glass of water to survive, and also have

\footnotetext{
18 This is partly because rural small-farm holders might lack the resources to more efficiently utilize land. See Xavier Irz, Lin Lin, Colin Thirtle and Steven Wiggins, "Agriculture Productivity Growth and Poverty Alleviation," Development Policy Review 19(4)(2001):449-466; Bob 2010 ibid.

${ }_{19}$ This is consistent with the claim that individuals are permitted to outsource their self-defence to others. See Helen Frowe, "If You'll Be My Bodyguard: Agreements to Save and the Duty to Minimize Harm," Ethics $129(2)(2019)$. Oberman claims not only that an individual is permitted to outsource their self-defense to another,
} 
a claim right to this water, it seems $X$ can hire $Z$ to physically stop $Y$ accessing this water, assuming the $Y$ does not need this water to survive. Because $X$ would be permitted to her own means to defend herself against an agent $Y$ liable to harm, she can permissibly use $Z$ 's means to defend herself against an agent $\mathrm{Y}$ liable to harm, assuming $\mathrm{Z}$ has consented to such defense. If citizens act permissibly in preventing others from entering land they live upon, but are unable to succeed in such prevention directly, they act permissibly in supporting members of parliament preventing others from entering this land. By extension, they act permissibly in supporting members of parliament implementing immigration controls which prevent migrants entering this land. At least, this is the case if only migrants liable to defensive harm are targeted (an assumption I shall remove in Section 4).

If the above argument is valid, it has implications for what migrants themselves are permitted to do as well. Sometimes a migrant has a claim right to land on the other side of a border. Perhaps she has a claim right because equality demands she access this land, or perhaps because it is necessary for her to have a sufficiently decent life, but not necessary for those currently occupying the land to have a sufficiently decent life. Whatever the reason, if she has a claim right to this land, and is also dependent upon it for survival, she can permissibly use necessary defensive force against border officials attempting to prevent her from accessing this land. After she has successfully crossed, she is permitted to defend this land by using defensive harm against those attempting to deport her, and other citizens attempting to undermine her access to this land.

In reality, a given migrant with a right to defensive force might be unable to utilize such force. Migrants generally have fewer legal rights than the citizens they live amongst, and fewer resources to hire guards to protect their land. As such, citizens have the ability to use permissible self-defense more frequently than migrants. This is an unfortunate implication of a broader theory of self-defense: some have greater means to defend themselves than others. It remains the case that, if either a citizen or a migrant does have the means to defend

\footnotetext{
but that a state in particular is "required to defend their citizens' rights when defense is permissible." I think this is true, but I am merely claiming that individuals are permitted to outsource self-defense when they are unable to do so. See Kieran Oberman, "The Myth of the Optional War: Why States are Required to Wage War they are Permitted to Wage," Philosophy and Public Affairs 43(4)(2015):255-286 at 273.
} 
themselves, they are permitted to do so to protect land they have a claim right over, and which only they depend on to survive.

The above analysis is limited to cases where individuals wish to defend land they directly utilize. A similar conclusion can be reached regarding indirect utilization.

Consider a Botswana citizen whose survival depends on state welfare, paid for partly from the diamond industry within the state's territory. ${ }^{20}$ Or consider a Rwandan citizen depending on state healthcare, paid partially from agricultural industries within the state's territory. ${ }^{21}$ If we accept that individuals have a claim right to land they are farming every square kilometer of, which they have planned their lives around, it seems they have a claim to land which they are not directly farming, but which they have planned their lives around. If an Ethiopian farmer has a claim right to land she has been farming because she has planned her life around this farmland, a Botswanan citizen has a claim right to some resources from the diamond industry she has planned her life around, and a Rwandan citizen has a claim right to some resources from agricultural industries she has planned her life around. If the Botswanan and Rwandan citizens are also dependent on these resources to survive, and will lack access to these resources if more than a given number of migrants arrive, then they can permissibly support preventing more than this number of migrants arriving.

\subsection{Jobs}

The above general reasoning has implications for another key resource: jobs. If one can have a claim right to land one has occupied and planned around for long enough, one can have a

\footnotetext{
${ }^{20}$ Jeremy Seekings, "Drought Relief and the Origins of a Conservative Welfare State in Botswana, 1965-1980," Centre for Social Science Working Paper No. 375, June 2016, accessed on 29 December 2019 at https://open.uct.ac.za/bitstream/handle/11427/21590/Seekings_Working\%20Paper\%20378_2016.pdf?sequence=1\& isAllowed $=\mathrm{y}$

${ }^{21}$ The healthcare is mostly paid for from individual compulsory health insurance payments, themselves often sourced from agricultural work, and taxation from the general budget. Foreign aid makes up less than half of the budget as of 2018. UNICEF, "Health Budget Brief: Investing in Children's Health in Rwanda," October 2017, accessed on 30 December 2019 at https://www.unicef.org/esaro/UNICEF_Rwanda_--_2017_-_Health_Budget_Brief.pdf; C. Sekabaraga, A. Soucat, F. Diop and G. Martin, "Innovative Financing for Health in Rwanda: A Report of Successful Reforms," in (eds.) P. Chuhan-Pole and M. Angwafo, Yes, Africa Can, pp. 403416, Washington, DC: The World Bank 2011, accessed on 30 December 2019 at http://siteresources.worldbank.org/AFRICAEXT/Resources/258643-1271798012256/Rwanda-health.pdf
} 
claim right to a job one has occupied and planned around for long enough. ${ }^{22}$ This idea is not radical; individuals in many countries have legal protections against being fired once they have worked in a job for long enough. ${ }^{23}$ Perhaps many more individuals, beyond those living in countries with such legal protections, have claim rights to their jobs. If they do and depend on these jobs for survival, but cannot depend on their government to protect them against being fired from such jobs, it seems they act permissibly in supporting immigration control necessary to protect their access to these jobs.

Even when a person has not worked in a job for a long time, and has not planned their lives around this job, they might still have a claim right to the job in certain circumstances. Sometimes a person has a claim right to a job because the job ought to be given to the most qualified candidate. For example, aid agencies sometimes hire Western aid workers from high-income countries, because those from high-income countries have contacts which increase their likelihood of obtaining a job, even when a local would be more qualified for the position, or equally as qualified and willing to work for less money. ${ }^{24}$ If we think the aid agency ought to hire the candidate who will best progress the aid agency's goals, ${ }^{25}$ and a local can best fulfil the agency's goals, the local has a claim right to this job which the Western aid worker does not have. Other most-qualified candidates might have similar justifications, including doctors, nurses, teachers, firefighters, soldiers, police officers, and civil servants; there are a range of positions which particular individuals ought to access, because they best help the populations which these positions are meant to help. In countries where a significant

\footnotetext{
${ }^{22}$ Of course, this claim needn't be absolute - a very inefficient person might lose their claim to the job - but the same holds true for land. A very inefficient person might lose a claim right to land that others can better utilize. Assuming someone is good enough at a job, working at it for long enough could give them a right to continue working at it.

${ }^{23}$ Michael Despax, Jean-Pierre Laborde and Jacques Rojot, Labour Law in France, New York/Amsterdam: Wolters Kluwer; Kenneth G. Dau; Geng-Shenq Lin, "The Protection of Employee According to the Tainwan Labour Standards Act," VNU Journal of Science: Legal Studies 34(2)(2018):26-34 at 32-33.

${ }^{24}$ For more on inefficiency in aid agency work, which could be the result of inefficient hiring practices, see Eva Svoboda, "Holding the Keys: Humanitarian access and local organisations," Policy Brief 70, Humanitarian Policy Group, January 2018, accessed on 10 December 2019 at https:/www.odi.org/sites/odi.org.uk/files/resourcedocuments/11982.pdf.

${ }^{25}$ Toby Ord, 'The Moral Imperative Towards Cost-Effectiveness in Global Health,' Centre for Global Development, March 2013, accessed on 10 December 2019 at http://amirrorclear.net/files/the-moral-imperative-towards-costeffectiveness-in-global-health.pdf. For more on the duties of aid agencies, see Niheer Dasandi and Lior Erez, "The Donor's Dilemma: International Aid and Human Rights Violations," British Journal of Political Science (Forthcoming); Jennifer Rubenstein, Between Samaritans and States: The political ethics of humanitarian INGOs, Oxford: Oxford University Press 2015.
} 
portion of the population works for the public and aid sectors, a significant portion of citizens may be the most qualified for at least one job, especially as they have knowledge of the language, norms, and terrain for providing assistance to locals. If such individuals have a claim right to at least one job, derived from the interests of the broader population, and are also dependent on this job to survive, they can permissibly support immigration control necessary to protect access to this job.

A final instance where an individual has a claim right to a job is when they would be wrongfully discriminated against if denied this job. For example, while hotel owners may not have any duty to hire the most qualified workers, they do have duties to not hire based on gender, relationship status, sexual orientation, and the color of candidates' skin. ${ }^{26}$ If a hotel owner refuses to hire a South Sudanese candidate because he has darker skin than northern Sudanese and Eritreans, and this candidate would have been hired were if not for discrimination, he has a claim right to the job. If increased immigration control is also necessary for obtaining this job, support for such control would be justified, assuming (for now) that those hired are not dependent for such a job to survive as well.

Many private firms do not engage in discrimination as described above, but hire family members from abroad, resulting in locals unable to access these jobs. If the motivation of such employers is to ensure family members have jobs, it is not clear if they engage in wrongful discrimination. Perhaps there are resources which individuals can permissibly give to family members, even when others are in much greater need. For example, an individual is permitted to buy gifts for loved ones, and not give all to charity. If there exist resources one can permissibly give to one's family, there can exist resources one can permissibly give to family in return for their labor. If this is true, then when an employer decides to hire fellow family members, it needn't entail impermissible discrimination. Locals would not have a claim right

\footnotetext{
${ }^{26}$ At least, this is wrong when discriminating against members of a worse-off group. For theories explaining why and when discrimination is wrong, see Deborah Hellman, When Is Discrimination Wrong? Cambridge, MA: Harvard University Press 2008; Kasper Lippert-Rasmussen, Born Free and Equal? A Philosophical Inquiry into the Nature of Discrimination, Oxford: Oxford University Press 2014; Shlomi Segall, "What's so Bad about Discrimination?" Utilitas 24(1)(2012): 82-100; Tarunabh Khaitan, A Theory of Discrimination Law, Oxford: Oxford University Press 2015; Richard Arneson, "What is Wrongful Discrimination?" San Diego Law Review 43(4)(2005):775-807; Larry Alexander, "What Makes Wrongful Discrimination Wrong?" University of Pennsylvania Law Review 14(1)(1992):149-219.
} 
to the jobs on discrimination grounds and so could not on these grounds support immigration control.

Let us assume, for a moment, that individual does have a claim right to a job, either on grounds of discrimination, on grounds of being the most qualified, or some other ground. If such an individual does have a claim right to a job, and is financially supporting someone else because they have access to this job, the recipient of this financial support may have a claim right to continued support dependent on this job. For example, if Ahmad has been supporting Beatrice for many years, than Beatrice might have a claim right to continued support, at least if Ahmad has consented to provide this support. She might have this claim right because she has become dependent upon this support for many years, or perhaps because this is what distributive justice demands. If she has a claim right to this support, and she will likely lose this support should Ahmad become unemployed due to an increase in inward migration, she might have a right to support immigration control which limits inward migration. She would have such a right if she were dependent on Ahmad's support to survive, but the migrants entering were not. In states where Beatrice's circumstances are typical, and a significant portion of the population depends on the charity of others to survive, a significant portion of the population may have self-defence grounds for supporting immigration control. This is true even if those who become unemployed either have no claim rights to these jobs or are not dependent on these jobs for survival.

\section{Survival Migrants}

Let us now consider cases where both citizens and migrants are dependent on land or jobs for survival, and migrants crossing borders to access such land or jobs places the lives of citizens at risk. Consider a case from the 1950s, when there was a relatively open border between Sudan and Uganda, and southern Sudanese began moving to Uganda to work in the cotton industry. As competition for land and firewood increased, conflict over these resources did as well, and citizens supported the government pressuring migrants to eventually repatriate. ${ }^{27}$

\footnotetext{
${ }^{27}$ Merkx 2002 ibid at 122-124.
} 
Such repatriation was increasingly encouraged in the 2000s, and many returned. ${ }^{28}$ It is not clear if citizens were justified in voting to support such pressure, given that those repatriating were dependent on resources in Uganda to survive. A similar dilemma arose between 1962 and 1964, when a recorded 378,656 Rwandan refugees arrived in Uganda. While citizens supported providing refuge, they called for refugees to remain in enclosed detention centres. ${ }^{29}$ One reason for this was land. In a mostly-agrarian society, permitting refugees to live wherever they desired might lead to conflict over access to natural resources. It is not clear if such restrictions were justified, given that refugees were dependent on land in other areas to survive.

I claim this: citizens are ultimately permitted to vote for parties denying entrance or free movement to an equal or lesser number of migrants if this is necessary to prevent migrants accessing jobs and resources which both citizens and migrants rely on to survive, but which only citizens have a claim right to.

Below is the argument in defense of this claim:

1. If $X$ and $Y$ both depend on a resource to survive, and only $X$ has a claim right to this resource, then $\mathrm{X}$ is permitted to forcibly prevent $\mathrm{Y}$ from intentionally using this resource.

2. Sometimes two individuals both depend on land to survive, but only one has a claim right to this land.

3. Therefore, the individual with a claim right to the land is permitted to use force to prevent the other individual from using this land.

4. Citizens permitted to use force are generally not able to do so directly.

5. When $X$ has a right to forcibly prevent $Y$ from accessing resources which she and not $\mathrm{Y}$ has a claim right over, and to save $\mathrm{X}^{\prime}$ s own life, she can permissibly support $\mathrm{Z}$ using force if this is necessary to prevent $\mathrm{Y}$ from accessing these resources.

\footnotetext{
${ }^{28}$ Refugees were rarely physically deported. Instead, they were denied legal status, and this hampered their ability to access employment. See Sarah Dryden-Peterson, "'I Find Myself as Someone who is in the Forest,': Urgan Refugees as Agents for Social Change," Journal of Refugee Studies 19(3)(2006):381-395.

${ }^{29}$ Ogenga Otunnu, "Rwandese Refugees and Immigrants in Uganda," in (eds.) Howard Edelman and Astri Suhrke, The Path of a Genocide: The Rwanda Crisis from Uganda to Zaire, New Brunswick/London: Transaction Publishing 1999 at 12 .
} 
6. Therefore, when citizens are permitted to use force against others attempting to utilize life-sustaining land, but are not able to use such force, they are permitted to support their government using such force instead, including using force via immigration control.

The first premise of the argument can be defended by appealing to a general principle of bodily autonomy. Sometimes, the only way to have control over our bodies is to have control over resources which we are dependent upon for our survival. If so, then others can only respect our bodily autonomy by granting us control over resources which we depend on for survival. This itself is not enough to create a duty on others to respect our bodily autonomy, because sometimes others are also dependent on these resources to protect their own survival. However, when others lack a claim right to the resources which we have, then others have a correlative duty to refrain from utilizing these resources, and so are obligated to respect our bodily autonomy over their own survival. If others fail to respect this autonomy, then they are liable to defensive force. For this reason, it is permissible for one to use force against others attempting to use such resources.

For example, imagine someone is hooked up to a ventilator for survival. If they have a claim right to this ventilator, they can permissibly use force against others trying to take the ventilator, even if others need it for survival as well. As before, whether one has a claim right over particular resources will depend on a broader theory of justice. One might hold that an individual has a claim right to a ventilator if they bought it under market conditions with fair equality of opportunity, or if they have been relying on it for some time, or some other conditions. What matters is that they can state, "I must use the ventilator to protect my body, and given that I also have a prior claim right to this ventilator, you ought not take this ventilator from me. If you try, you are liable to my defensive harm." 30

\footnotetext{
${ }^{30}$ For similar claims, see Quong 2010 ibid at 527; Ferzan 2011 ibid. Some might reject the conclusion that such agents are liable to defensive harm. If such agents are dependent on a resource for survival, and they attempt to use this resource for survival, they are like innocent threats: they are innocent because they are not voluntarily choosing to take the resource, given that they have no reasonable alternative. The only alternative is death. If one accepts this, one might still accept a more modest premise: an individual with a claim right to a resource, and who is dependent upon it for survival, has a liberty right to use force against the other agent attempting to use this resource, even if the other agent has a liberty right to fight back.
} 
Consider, now, the second premise: sometimes two individuals rely on land to survive, but only one has a claim right to this land. As with the examples in Section 1, it is difficult to establish when citizens have claim rights over land, but let me reiterate the popular view described in Section 1: individuals have a claim right to land if they have been living on it for some time, the land is necessary to plan their lives, and they have a reasonable expectation that they can utilize the land for into the future. ${ }^{31}$ These conditions were met for the citizens in 1950s and 1960s Uganda: individuals had been living and cultivating particular tracks of land for many years, and had planned their lives around this cultivation with the expectation they could continue to in the future. If it is permissible to prevent others accessing a resource that one depends on for survival and has a claim right over, which others do not have a claim right over, citizens in Uganda could permissibly use force to prevent others from accessing the land they were dependent upon for survival.

As before, sometimes citizens are unable to use force to prevent others accessing their land. The most they can do is vote for members of parliament who support policies which exclude potential migrants attempting to enter the state entirely.

In such cases, citizens are permitted to support immigration control because of the final premise: When $\mathrm{X}$ can permissibly and forcibly prevent $\mathrm{Y}$ from accessing resources which $\mathrm{X}$ and not $Y$ has a claim right over, and to save $X^{\prime}$ 's own life, she can permissibly support $Z$ using such force instead if this step is necessary to prevent $\mathrm{Y}$ from accessing the resources. For example, if I have a ventilator which I have a claim over and am dependent on for survival, I am permitted to support a hospital administrator using force to prevent another person entering the hospital, if my supporting this hospital administrator's actions is the only way I can prevent this person from taking the ventilator. Note that this claim is not dependent on the hospital administrator acting permissibly; as a third party she may not be permitted to prevent others from entering the hospital, a possibility I address in the next section. Here I merely claim that, when we are attempting to save our own lives, we can permissibly support others protecting resources we have a claim right over and depend on for survival. For this

\footnotetext{
31 Stilz 2011 ibid and 2013 ibid; Waldron 1992 ibid; Nine 2018; Goodin 1991; Heller and Serkin 1999 ibid.
} 
reason, citizens can permissibly support policymakers limiting the rate of inward migration, when this is necessary to protect life-sustaining land.

The same key claim regarding resources is applicable to jobs: when both $\mathrm{X}$ and $\mathrm{Y}$ are dependent upon a job for survival, but only $\mathrm{X}$ has a claim right to this job, $\mathrm{X}$ can permissibly use force against $Y$ to continue accessing this job. As with the claim from the last section, this raises the question of when one has a claim right to a job. One scenario, as before, is where one has been working in a particular job for a long time with the expectation they will continue working in this job into the future. Another scenario is where one is the most qualified in a job where the most qualified ought to be hired, and a third scenario is where one would have been hired had it not been for wrongful discrimination.

I argued in the last section that one is not necessarily a victim of wrongful discrimination if a private business owner decides to hire family members, even if family members are not dependent on jobs for survival but citizens are. Even if one rejected this conclusion, it seems even more clearly true when businessowners are hiring family members who are dependent on jobs for survival. This is because it is generally permissible to save family members before others, and wrong to force individuals to save others before their family members (all else being equal). An individual can use her lifeboat to save her father before using a lifeboat to save a stranger. She can, by extension, throw a lifeboat to her father in exchange for her father's labor before throwing a lifeboat to a stranger in return for the stranger's labor. ${ }^{32}$ Her actions are permissible, and it would be impermissible for the drowning victim to force her to save himself rather than her father. Just as it would be wrong to force someone to sacrifice their own life to help another, it would be wrong to force this individual to sacrifice her father to help another. The same holds true for those who have legitimate ownership over firms, and wish to hire family members who would otherwise not survive. Such business owners act permissibly, and a third party acts impermissibly in preventing the business owner from hiring a family member so that the third party is hired instead.

\footnotetext{
${ }^{32}$ Assume she can only afford the life boat if her father works for her after being saved, such that the trade is not exploitative.
} 
In reality, many business owners hire co-nationals who are not close relatives. Whether one has a right to hire co-nationals over locals in scenarios where both lives' are at risk will depend on whether one is permitted to save the lives of co-nationals before others. Some claim this is permissible ${ }^{33}$ and some claim it is not. ${ }^{34}$ Even if it is not, it may be permissible to save the lives of friends, acquaintances, professional associates, and others before strangers. Individuals might strongly desire to save those they know over those they don't. If liberalism requires that the state be neutral about the sorts of relationships individuals have a right to partake in - the state, for example, should not encourage strong familial ties over friendships ${ }^{35}$ - then the state should permit individuals to save those they know over those they do not, rather than only permit individuals to save those they are related to over those they are not. Citizens should permit such choices as well, and act wrongly in supporting immigration controls that undermine such choices.

When citizens wrongly support immigration controls that undermine such choices, then migrants themselves have a right of self-defense. They might be permitted to use force to protect access to resources and jobs which citizens attempt to utilize for their own survival, but which citizens do not have a claim right to. Migrants, for example, are permitted to hire guards to protect life-sustaining jobs in their firms if these migrants have claim rights to these jobs which locals do not have. Unfortunately, migrants are often unable to utilize defensive force in such cases: we live in a world where, when citizens are permitted to act in self-defense by restricting migration, they usually have the power to do so, but when migrants are permitted to act in self-defense against non-migrant citizens, they lack the same power to do so. When migrants lack such power, then a distributive injustice has occurred: migrants have less power to act in permissible self-defense. Such distributive injustice might create a reason for third parties - such as NGOs, and perhaps citizens not acting in self-defense themselves -

\footnotetext{
33 Seth Lazar, "Authorization and the Morality of War," Australasian Journal of Philosophy 94(2)(2016):211-226 at 220; Hurka, T. 2005. "Proportionality in the Morality of War," Philosophy \& Public Affairs 33(1)(2005): 34-66; Francis Kamm, “Terror and Collateral Damage: Are They Permissible?" The Journal of Ethics 9/34: 381-401.

${ }^{34}$ Javier S. Hidalgo, Unjust Borders: Individuals and the ethics of immigration, Routledge 2019 at 37-41.

${ }^{35}$ Luara Feroccioli provides a compelling reason for the state to avoid endorsing certain familial ideals over other types of relationships. See at Luara Ferracioli, "Family Migration Schemes and Libera Neutrality," Journal of Moral Philosophy 13(5)(2016):553-575 at 558-561.
} 
to defend the rights of migrants so that migrants can defend themselves. It remains the case that some citizens do no wrong in supporting immigration restrictions.

\section{Jobs, Land, and Pandemics}

Perhaps today's most uncontroversial form of immigration control is the establishment of temporary restrictions in light of the Covid-19 pandemic. I defend two claims:

1. When the entrance of migrants increases an infection rate during a pandemic, and particular citizens are less able to safely access life-sustaining jobs and land as a result, they can justifiably support migration restrictions if citizens depend on these jobs and land to survive, and migrants do not depend on entering the state to survive.

2. When migrants do depend on migrating to survive, but migrants will not utilize land or jobs which only citizens have a claim right to, then citizens do not have self-defence grounds to restrict immigration. However, they might still have other grounds to restrict immigration.

The first claim can be defended along the following lines:

1. If $X$ has a claim right to a resource, and only $X$ is dependent on this resource to survive, she is permitted to use force against $\mathrm{Y}$ to prevent $\mathrm{Y}$ from blocking access to this resource, (assuming blocking access to this resource is proportionate, and so entails less than a given threshold of harm).

2. Sometimes citizens have a claim right to jobs or land and also need these jobs or land to survive.

3. These citizens are therefore permitted to use force to prevent others from blocking access to a given job or piece of land which only they depend on to survive.

4. One way citizens might use force to prevent others from blocking access to a job or land is by preventing others from increasing the prevalence of a pandemic which renders accessing a job or land unsafe.

5. When $X$ is permitted to use force against $Y$ to access resources she has a claim right to, and which only she needs to survive, she can permissibly support $Z$ utilizing such force if she is unable to do so herself.

6. Therefore, when citizens have a claim right over land or a job which only they depend on for survival, but they are unable to directly prevent the spread of a pandemic that 
blocks access to these jobs or land, they can permissibly support a government preventing the spread of this pandemic via immigration control.

The first premise concerns instances where an agent protects a resource not from someone who seeks to utilize this resource, but from someone whose actions will block access to this resource. If two individuals have a joint claim right to a glass of water that only one depends on for survival, it seems the one who needs the water for survival can permissibly use force to prevent the second from blocking access to this water.

This seems true even when the second is only indirectly blocking access to this water. Imagine if the second person is playing catch with her daughter, who will likely throw the ball to a third person, who will throw it to a fourth person, who will throw it to a firth, and so forth, with one of the many people likely throwing poorly, with the ball hitting the water, knocking it over. It seems the individual dependent on the water can use force to prevent the second person from beginning the game of catch, given that this will indirectly increase the odds of the water spilling over. Of course, if the odds of increased water-spillage are infinitesimal, then perhaps the joy of the game outweighs the benefits of survival, but assuming the total odds are above a given threshold, it seems force is justified as a matter of self-defense.

When individuals have a claim right to land or a job (or the resources from land or a job), they can similarly use force to prevent others blocking access to this land or job, whether the access is blocked directly or indirectly. For example, if an individual would normally access a lifesustaining job via a given road, and others seek to set up a checkpoint on this road, she can use force against these other check-point builders, assuming this force (and the dismantling of the checkpoint) creates less than a given threshold of harm. This person can similarly use force against those who will block her access to this job indirectly via the spread of a pandemic. Imagine that a small group of individuals enjoy standing around the entrance to the road which she uses to access her job, and these individuals' close proximity to themselves and her renders them likely disease carriers. In order for her to access the road safely, and thus access her job, she can permissibly use necessary force to disperse the group (assuming such force is also proportionate). 
When a major increase in migration renders roads crowded, then an individual may be unable to personally disperse crowds. In such scenarios, the most effective way to protect safe passage to jobs and land is to limit inwards migration using force at the border. The woman above would be acting permissibly in outsourcing such force to her government, voting for immigration restrictions until the pandemic no longer poses a risk to her life-sustaining job. Many citizens will not experience increased risk at their jobs or on their land in the above manner, because they will be unable to safely access jobs or land regardless of immigration. They will be impacted by the pandemic to such a degree that they will not travel regardless of whether more migrants arrive. More importantly, many do not have jobs or land which they will be unable to safely access with a further spread of the pandemic. For all such individuals, the risk from a pandemic arises not from traveling to a particular job or land, but only from other activities. Some of these activities entail access to services which they have a claim right to. For example, some might be exposed to a virus via a caretaker which an individual might have a claim right to, and which they are also dependent upon to survive, in which case the same general reasoning described above applies: when an increase in migration increases the chances that their caretaker will be exposed, then an increase in migration will block safe access to caretaking, and they have a right to restrict the entry of immigrants who do not require migration to survive.

Here are the more complicated cases: sometimes citizens risk being exposed not to anything they have a claim right to and depend upon to survive, but to things they have no claim right to or which they do not depend on to survive. Individuals might be exposed to a virus while walking on the street, touching the surface of food, opening the door handles to the entrance of shops, or frequenting public parks. Such individuals unlikely have a claim right to the particular sidewalks, surfaces, door handles or parks they come into contact with. Even if they do, they are unlikely dependent on such sidewalks, surfaces, door handles or parks to survive. It is simply that they might not survive if they touch such objects and frequent such spaces. When this is the case, two further claims might hold true. It might be the case that self-defence includes defending a certain minimal standard of life, rather than just life itself, and this standard of life cannot be met without immigration restrictions. Assuming citizens have a claim right to some minimal amount of safe space (perhaps because they have planned their lives around this space) and assuming this amount of space is also necessary for living a 
minimally decent life, and assuming one has a right to use force against individuals who threaten a minimally decent life when such individuals (a) have no claim right to this space or (b) do not require this space for a minimally decent life, then citizens have a right to use force against migrants who threaten this way of life and either (a) have no claim right to this space or (b) do not require this space for a minimally decent life.

If one rejects one of the above premises, this needn't imply that immigration restrictions to prevent the spread of an epidemic are never justified. They are simply justified for reasons other than self-defence. One potential justification appeals to aggregate benefits: when the aggregate benefits arising from immigration restrictions are considerably enough, then such restrictions might be justified. Pandemics might fall under this category in some cases.

\section{Necessity and Proportionality}

The analysis thus far, which outlined when citizens have self-defence grounds to support immigration restrictions, assumed that citizens were fulfilling the conditions of necessary, because their votes were necessary for them to continue accessing life-sustaining resources. The analysis also assumed that the conditions of proportionality were met: it seems proportional for citizens to prevent a number of migrants seeking entrance which is equal or lesser than the number of citizens whose lives are at risk, if citizens but not migrants lives are at risk, or if citizens but not migrants have a claim right to the resources which both depend on to survive.

I remove these assumptions in this section, and consider more precisely when and whether the necessary and proportionality conditions are met. I demonstrate that citizens often fulfil these conditions when voting for policymakers supporting immigration restrictions, but the policymakers they vote for do not fulfil these conditions themselves.

\subsection{Necessity}

Here is one reason that necessity might not be fulfilled. Sometimes most citizens do not support a comprehensive welfare state but, if they did, anyone negatively impacted by immigration would be assisted, such that the negative effects of immigration would be 
avoided. These citizens do not fulfil the necessity condition, because supporting immigration control is not necessary to save their own lives or others.

Though these citizens do not fulfil the necessity condition, a minority of citizens who do support a welfare state, but cannot persuade the majority to think otherwise, do. If they are permitted to use force to prevent others from accessing live-sustaining resources they have a claim right to, they are permitted to use whatever means are necessary to utilize such force. Because the only means they have is a vote for members of parliament who will prevent inward migration, given the attitude of most other citizens, these means are justified.

The same conclusion holds for a given member of parliament who is not successful in persuading the majority of parliament or citizens to support a welfare state. Assuming this member of parliament cannot protect a given citizen through means other than supporting immigration controls, given the opinions of most parliamentarians and citizens, this member of parliament can permissibly implement such controls.

The same conclusion holds when the majority of citizens support a welfare state, but a key constituency does not, and this key constituency has bargaining power to prevent or limit the scope of this welfare state. Such is partly the case in Botswana. Though the country has a strong welfare program, the interests of wealthier cattle-owners and diamond-industry leaders often taken precedent over the interests of the majority rural poor. ${ }^{36}$ Were the state to suddenly open its borders to all, it is unlikely that the majority rural poor would succeed in persuading the minority wealthy to redistribute enough wealth to offset negative short-term effects of migration. For the majority rural poor, voting for immigration control is necessary to protect their own lives.

Finally, sometimes the majority of citizens support a welfare state but the majority of parliament does not, or the executive branch does not, because parliament or the executive do

\footnotetext{
${ }^{36}$ Marianne S. Ulriksen, “Welfare Policy Expansion in Botswana and Mauritius: Explaining the Causes of Different Welfare Regime Paths," Comparative Political Studies 45(12)(2012):1483-1509 at 1494; Christopher Colclough and Stephen McCarthy, The political economy of Botswana: A study of Growth and Distribution. Oxford, UK: Oxford University Press 1980 at 47.
} 
not perfectly represent the will of citizens. In South Sudan, members of parliament tend to officially support welfare provisions to help the poorest members of society, but their policies are nonetheless rarely implemented in practice, given widespread military spending and corruption amongst members of the civil service. ${ }^{37}$ Because welfare provisions are not implemented, the effects of permitting all potential migrants to enter could be life-threatening for citizens who face unemployment. Such citizens and their members of parliament may therefore be justified in supporting some controls on inward migration, as the latter recently did in 2017.38

The above conclusion has an important implication: sometimes individual citizens and parliamentarians do no wrong in supporting immigration control, but the state as a whole does. This is true if we assume that:

a. The state as a whole is constitutive of parliamentarians, citizens, and civil servants and

b. When claiming the majority of parliamentarians, citizens, and civil servants ought to implement a given policy, this is tantamount to claiming the state ought to implement this policy.

If the majority of citizens, parliamentarians and civil servants ought to implement a welfare state, but do not, then the state acts wrongly in failing to implement the welfare state. Similarly, if the majority of citizens, parliamentarians and civil servants limit inward migration to save the lives of citizens, but must only limit inward migration to save lives because they have failed to support a welfare state, they act wrongly in limiting inward migration. They act wrongly because they engage in force which is not necessary for saving

37 African Development Bank Group, “The Political Economy of South Sudan," ADB/BD/IF/2018/211ADB/BD/IF/2018/159, RDGE/ECCE/RDTS Departments, accessed on 30 December 2019 at https://www.afdb.org/fileadmin/uploads/afdb/Documents/Generic-

Documents/The_Political_Economy_of_South_Sudan.pdf.

${ }^{38}$ While the state lacks the capacity to prevent migrants from entering, it has required that $80 \%$ of manual laborers in some sectors have South Sudanese citizenship. It has also expressed and received some support for "manage its borders," which in other contexts refers to the use of force to prevent migrants from entering. See Jale Richard, "Parliament Passes Labour Bill," Gurtong 15 November 2017, accessed on 30 December 2019 at http://www.gurtong.net/ECM/Editorial/tabid/124/ctl/ArticleView/mid/519/articleId/21063/categoryId/6/Parliame nt-Passes-Labour-Bill.aspx and International Organisation for Migration, "South Sudan's First Migration Policy Takes Another Step," 27/2/19, accessed on 30 December 2019 from https://www.iom.int/news/south-sudans-firstmigration-policy-takes-another-step-forward 
citizens' lives. We can therefore claim the state acts wrongly towards the migrants it prevents from entering. It remains the case that a minority of citizens and parliamentarians who do support a welfare state do no wrong, if they support a welfare state but cannot persuade others to follow suit.

When the above scenario occurs, we can make a further claim: the state does not merely wrong would-be migrants, but wrongs citizens and parliamentarians who must support immigration controls due to a lack of welfare support from the majority or powerful minority.

To see why, consider this compelling premise: we wrong others when forcing them to causally contribute to the harming of others, assuming such force is itself wrong for independent reasons. For example, if $\mathrm{X}$ puts a gun to $\mathrm{Y}^{\prime}$ s head and threatens to kill her unless she punches $\mathrm{Z}$, she wrongs $\mathrm{Y}$ both by putting a gun towards $\mathrm{Y}^{\prime}$ s head, and also by placing $\mathrm{Y}$ in a position where she must choose between dying or punching Z. ${ }^{39}$ When the majority of citizens refuse to support a welfare state, and ought to, or when members of parliament and the executive refuse to support a welfare state, and ought to, they commit a wrong against citizens who now must choose between risking their lives or avoiding harm against would-be migrants. These citizens are harmed by the majority or powerful minority who place them in a position where they must harm migrants to save their lives. While they act permissibly in harming migrants to save their lives, they are wronged in being forced into this position to begin with.

\subsection{Proportionality}

Even when votes in support of immigration control fulfil the necessity condition, they might fail to fulfil the proportionality condition. More specifically, voters might lack both wide and narrow proportionality.

Wide proportionality refers to defensive harm which is permissible to inflict on innocent bystanders who are not liable to harm. For example, shooting someone who is about to kill you might lack wide proportionality if the bullet will kill three innocent bystanders as well.

\footnotetext{
${ }^{39}$ In such cases, $X$ is engaging in what Stephen White calls an "illicit transfer of responsibility" to $Y$, in that she wrongly forces $Y$ to be the agent responsible for whether or not $Z$ is harmed. See Stephen White, "On the Moral Objection to Coercion," Philosophy and Public Affairs 45(3)(2017):199-231 at 228.
} 
Narrow proportionality refers to defensive harm permissible to inflict on those who are liable to such harm. For example, if it is necessary kill a man to prevent him from pinching you once, then killing him would lack narrow proportionality. ${ }^{40}$

Immigration control is a blunt instrument, and so risks violating wide proportionality. In the pursuit of preventing migrants from entering who are liable to defensive harm, border officials will inevitably deny entrance to many migrants who are not liable to defensive force. Even if border officials could in theory deny entrance only to those liable to defensive harm, policymakers may still call for restricting migrants not liable to defensive harm, and citizens may need to vote for such policymakers to protect their land and jobs. These citizens act impermissibly if, in voting for such policymakers, they contribute to harming such a large number of non-liable migrants that the restrictions lack proportionality.

For example, imagine a US citizen will lose her job if new immigrants arrive, and she is dependent on her job to continue accessing life-saving medical treatment via her employee insurance. She has a choice between voting for one of two parties: the Democrats that year support immigration levels similar to previous years, and the Republicans support a major decrease in immigration, including preventing refugees from entering. Neither party supports sufficient public healthcare to ensure she can maintain medical treatment should she lose her job. Even if an elected Republican party is necessary to save her life, given her limited options, she acts impermissibly in voting Republican if the number of migrants excluded are high enough. There is a limit to the number of individuals she can permissibly support excluding to save her own life, when such exclusion will lead to the death of these individuals, and in particular the death of individuals not liable to harm. This seems true even if her intention is only to prevent a number of migrants from entering which would be proportionate to prevent from entering; if she can foresee that the number of innocent migrants denied entrance as a result of Republicans winning will far surpass the lower number she intends to prevent entering, her actions are wrong.

40 M. J. Fish, "An Eye for an Eye: Proportionality as a Moral Principle of Punishment," Oxford Journal of Legal Studies 28(1)(2008):57-71; Jeff McMahan, "Proportionate Defense," Journal of Transnational Law and Policy 23 (1)(2014):1-35. 
This observation has been overlooked in discussions on immigration control. As noted in the introduction, philosophers almost all accept that states only have a duty to grant entrance up until granting further entrance risks their own lives, after which they do not hold such a duty. ${ }^{41}$ I believe they can hold such a duty. Citizens can hold such a duty if the number who would be killed from being denied entrance is great enough.

This is not to claim that the number of migrants a citizen can permissibly support excluding must be equal or less than the number of individuals who would be killed from inward migration. Imagine a citizen's vote for a given party will predictably prevent two migrants from entering, and who will die without entering. This vote might be a proportionate response; perhaps we are permitted to take actions which will predictably and lethally harm two individuals to save our own lives, or even three or four. This is because humans have an "agent-relative prerogative": they are generally permitted to prioritize their own lives over others, at least to an extent.

Even when citizens have an agent-relative prerogative to support force which will harm more than one migrant, the policymakers they vote for may not be. They might only be permitted take actions which will predictably and lethally harm one migrant. In lethally harming one migrant, they have the combined justification: they help citizens save themselves, and they minimize harm, given that citizens have a claim right to the resources in question and migrants do not. No such combined justification arises if the number of migrants who die is more than one: if two migrants die for every citizen saved, then we not plausibly claim that the harm towards migrants is less than the harm towards citizens.

\footnotetext{
${ }^{41}$ Arash Abizadeh, "The Special-obligations Challenge to More Open Borders," in (eds.) Sarah Fine and Lea Ypi, Migration in Political Theory, Oxford: Oxford University Press 2016; Joseph Carens, "Aliens and Citizens: The case for open borders," Review of Politics 49(2)(1987): 251-273 at 259; Luara Ferracioli, "The Appeal and Danger of a New Refugee Convention,' Social Theory and Practice 40(1)(2014):123-144 at 132; Michael Dummett, On Immigration and Refugees, London and New York: Routledge 2001 at 14 and 50-52; Anna Stilz 2019 ibid at 175. An exception to this view is Hidalgo, who holds that borders should be open unless the total benefits outweigh the total harms. I take this view to be overly-demanding, as it does not permit agents to prioritize their own lives over others. See Hidalgo 2019 ibid at 57.
} 
An implication of this is that, if all act as they ought to, and if citizens can only protect their lives by excluding more migrants than the number of citizens protected, then citizens will be unable to successfully exclude the number of migrants they are permitted to exclude. This number will be constrained by the number which policymakers are permitted to exclude on their behalf.

For example, imagine that 100,000 citizens were permitted to each vote for immigration control, because immigration control would prevent three migrants per person from filling jobs which would otherwise go towards these citizens. This would not necessarily mean they collectively prevented 300,000 migrants from entering, because any given three migrants might end up causing unemployment to more than one citizen, but for simplicity assume no overlap: all 100,000 of these citizens act permissibly in supporting immigration control against 300,000 migrants. They act permissibly, in other words, in voting for policymakers preventing 300,000 migrants from entering. The parliamentarians they vote for may still act impermissibly in excluding these 300,000 migrants. For them, it might only be permissible to exclude 100,000 .

\section{Conclusion}

This article defended the premise that individuals are permitted to use force to protect certain resources or jobs which they have a claim right over, and which they rely on for survival, assuming the harms they cause are proportionate and necessary. When individuals are unable to use force themselves, they can permissibly outsource such force to others. Citizens are therefore permitted to authorize parliament to protect life-sustaining resources and jobs which citizens have a claim right over, and which migrants do not. They are permitted to prevent inward migration even in cases where parliament could implement more generous welfare programs, where these welfare programs would prevent the negative impacts of migration. So long as individual citizens are powerless to pass legislation implementing such welfare programs, they are permitted to support limits to migration necessary to protect their own lives. Though they act permissibly, parliament may not: parliament acts impermissibly when its actions are not necessary to save citizens' lives, as is often the case. And for both 
parliament and citizens, support for immigration control is impermissible if the number of migrants excluded are high enough. 